\title{
Environmental and Occupational Health Impact of Bauxite Mining in Malaysia: A Review
}

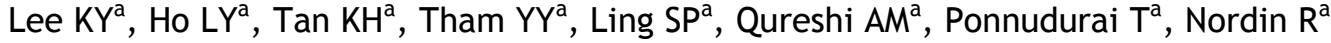

${ }^{a}$ Jeffrey Cheah School of Medicine and Health Sciences, Monash University Malaysia

\begin{abstract}
In the perspective of recent bauxite mining in Malaysia, this review aims to identify the potential environmental and health impacts on miners and surrounding communities. The environmental issues of bauxite mining include, air, water and soil pollution due to bauxite dust; leaching of bauxite into water sources resulting in reduced soil fertility as well as affecting agricultural food products and aquatic life. Bauxite occupational exposure affects the health of miners, and has negative consequences on the health of surrounding communities, such as increased respiratory symptoms, contamination of drinking water, other potential health risks from ingestion of bauxite and heavy metals, including noise-induced hearing loss and mental stress. This review discusses the processes of bauxite mining, its constituents and residual trace elements, and their impact on the environment and health of exposed workers and communities. It also explores the Malaysian legal requirements and standards of occupational exposure to bauxite.
\end{abstract}

Keywords: Bauxite mining, occupational and environmental health impact, Malaysia

\section{INTRODUCTION}

Aluminium $(\mathrm{Al})$ is the most plentiful metal in earth's crust, representing more than $7 \%$ by weight, and is the third most abundant element after silicon and oxygen ${ }^{1}$. Because aluminium is highly reactive, it is mostly found in oxidised form, of which approximately 250 different minerals exist ${ }^{1}$. Due to high chemical reactivity, aluminium is never found in the elemental state ${ }^{1}$. In terms of production, bauxite is the main source of the world's aluminium, supplying $99 \%$ of metallic aluminium ${ }^{1,2}$. Many minerals including feldspars contains aluminium, but extraction from these is expensive and requires high energy compared to bauxite ${ }^{3}$.

Bauxite was first discovered near the town of Les Baux in France, and was named after that town. It is the principal ore of alumina $\left(\mathrm{Al}_{2} \mathrm{O}_{3}\right)$ which is an immediate precursor in aluminium production ${ }^{2}$. Having reddish-brown colour, bauxite is a naturally occurring heterogeneous material and composes of one or more aluminium hydroxide minerals, principally gibbsite $\left[\mathrm{Al}(\mathrm{OH})_{3}\right]$, boehmite $[\gamma-\mathrm{AlO}(\mathrm{OH})]$

Corresponding author:

Prof Dr Rusli Bin Nordin

Jeffrey Cheah School of Medicine and Health

Sciences

Monash University Malaysia

No. 8, Jalan Masjid Abu Bakar

80100 Johor Bahru, Johor, Malaysia

Email: rusli.nordin@monash.edu

Tel: +6072190629

Fax: +6072243311 and diaspore $[\mathrm{a}-\mathrm{AlO}(\mathrm{OH})]^{4}$. In addition, other compounds are also found in bauxite such as hematite $\left[\mathrm{Fe}_{2} \mathrm{O}_{3}\right]$, goethite $[\mathrm{FeO}(\mathrm{OH})]$, quartz $\left[\mathrm{SiO}_{2}\right]$, rutile/anatase $\left[\mathrm{TiO}_{2}\right]$, kaolinite $\left[\mathrm{Al}_{2} \mathrm{Si}_{2} \mathrm{O}_{5}(\mathrm{OH})_{4}\right]$ with impurities in traces ${ }^{4}$. Trace elements found in bauxite include arsenic, beryllium, cadmium, chromium, lead, manganese, mercury, nickel and naturally-occurring radioactive materials such as uranium and thorium ${ }^{2}$. These elements often remain attached to the bauxite residue even after alumina extraction ${ }^{2}$.

Bauxite is formed as a weathering product of low iron and silica bedrock ${ }^{1,4}$. The weathering process involves the exposure of various igneous, sedimentary, and metamorphic rocks to the tropical and subtropical climates for millions of years ${ }^{2}$. Ninety per cent of bauxite resources in the world can be found in tropical areas while the rest in other latitudes have been exposed to prolonged weathering in their geological past ${ }^{2}$. Large bauxite reserves are found in Central and South America particularly in Brazil, Guinea and Australia, ${ }^{2,4}$. In Malaysia, bauxite resources are mainly located in Bukit Batu, Bukit Gebong, Lundu-Sematan, and Tanjung Seberang in Sarawak, Bukit Mengkabau and Labuk Valley in Sabah, Sungai Rengit and Teluk Ramunia in Johor, and Bukit Goh in Kuantan, Pahang ${ }^{5}$.

Bauxite can be extracted from the surface or underground deposits. Most bauxite occurs near the surface of earth with 1 or 2 meters of overburden consisting of top soil and vegetation ${ }^{2}$. In addition, 
underground deposits occur due to covering of other materials over bauxite after it has been formed, and require underground mining to extract these deposits economically ${ }^{2,4}$. Surface mining is more often carried out compared to underground mining because most of bauxite deposits occur close to the surface. Bauxite is thus extracted by shallow, open-cut mining using open-pit method from large blanket-type lateritic deposits, which are 4-6 meters thick under an overburden of up to 10 meters thickness ${ }^{6}$. The deposits vary in thickness and most can be mined and processed without further treatment to concentrate the mineral through process of beneficiation. However, bauxite ore from northern Brazil and Vietnam has a high clay content, and has to be washed before processing $^{3}$. Underground deposits require underground mining to extract them economically.

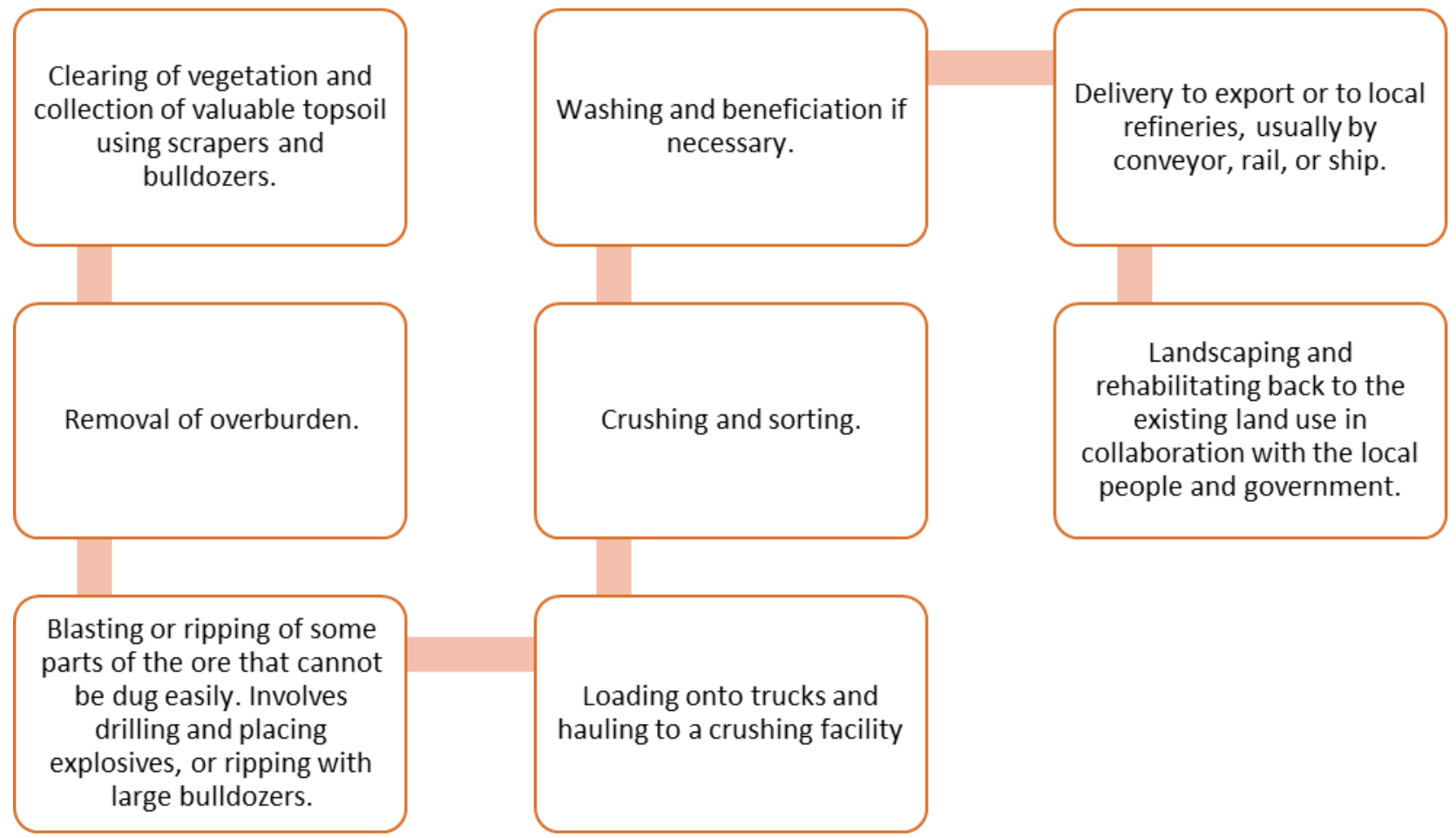

Figure 1: Typical processes involved in surface mining of bauxite deposits ${ }^{3}$

Bauxite ore is then refined into alumina $\left(\mathrm{Al}_{2} \mathrm{O}_{3}\right)$ by Bayer process, where these aluminium-containing minerals are dissolved in hot sodium hydroxide $(\mathrm{NaOH})^{6}$. The insoluble solids (bauxite residue, mud and sand) are washed, or partially neutralized (using $\mathrm{CO}_{2}$ or seawater treatment), and deposited in impoundments around the refinery using wet (yielding $15-30 \%$ solids) or dry (with $50-65 \%$ solids) disposal techniques ${ }^{6}$. Most of alumina then undergoes the Hall-Heroult electrolytic process to be transformed into aluminium.

Approximately two to three tonnes of bauxite are required to produce a tonne of alumina as bauxite only contains $30-54 \%$ alumina ${ }^{1}$. Four to six tonnes of bauxite are required to be purified to produce one tonne of aluminium metal. Compared to refining of bauxite and electrolytic reduction of alumina, bauxite mining consumes only a small amount of energy.

Current, global bauxite resources has been estimated at more than 70 billion tonnes, with the largest concentration in Guinea, where an estimated 25 billion tonnes of bauxite might be present $^{3}$. It is projected that there are sufficient economically viable reserves of aluminium to last another 100 years to supply for current demand ${ }^{1}$. There is a growing need for bauxite due to increasing demand for quality aluminium products, and new reserves are to be discovered for economic viability ${ }^{1}$.

Other than bauxite, alternative sources of aluminium include kaolin clay, oil shale, coal wastes and mineral anorthosite 6 . However, bauxite reserves are plentiful and economically cheap compared to these alternatives; therefore, technologies to process alternatives into aluminium are not expected to progress beyond the experimental stage ${ }^{4}$.

Recently, there appears to be concerns about the impact of bauxite mining not only towards the environment, but also on the health of population, especially in Kuantan. Mining areas are situated within residential zones, which lead to worries among the general public of its effects. Environmental pollution due to bauxite mining remains a concern not only because of direct pollution, but also due to detrimental short and long term effects. However, there is a lack of studies 
especially in Malaysia on this matter, justifying the need for a review to allow better understanding of its impacts, the standards of exposure and the laws pertaining to bauxite mining.

This paper aims to provide a general review of the impact of bauxite mining and its contents on the environment and individuals' health, and to encourage detailed research in this area.

\section{MATERIALS AND METHODS}

\section{Search strategy}

First of all, Google Scholar search and BMJ were used to better understand bauxite mining and its effects. Cochrane library was then used for further research as it provided higher quality articles. On Google scholar, the keywords used were "bauxite Malaysia review", and the limit was set to "where my words occur".
When it came to obtaining literature for the review, relevant research concerning environmental and occupational health impact of bauxite mining was identified by searching on Ovid Medline and PubMed. In order to ensure that relevant studies were not missed, the search terms remained broad.

Using PubMed, keywords such as "bauxite", "health impact", "aluminium oxide", "bauxite refining", "bauxite mining respiratory", "bauxite mining occupational" were searched.

The bulk of the research was done on Ovid Medline because of its extensive library of research papers that allows a comprehensive search using the Medical Subject Headings (MeSH) and "Additional Limits". No language restrictions were employed, and any paper published until $31^{\text {st }}$ August 2016 was reviewed. The following shows the relevant keywords used to narrow down our search:

\begin{tabular}{|c|c|}
\hline Topic & Keywords \\
\hline Accidents & Accidents, Occupational \\
\hline Adverse effects & Adverse effects \\
\hline Air pollutants & $\begin{array}{c}\text { Air pollutants, Air, Pollutant, Occupational, } \\
\text { Analysis, Adverse effects }\end{array}$ \\
\hline Bauxite & Aluminium oxide, Aluminium, Oxide, Bauxite \\
\hline Bauxite mining & $\begin{array}{l}\text { Aluminium oxide, Aluminium, Oxide, Bauxite, } \\
\text { Mining }\end{array}$ \\
\hline Dust Analysis & Dust, Analysis \\
\hline Forced expiratory volume & $\begin{array}{c}\text { Forced expiratory volume, Forced, Expiratory, } \\
\text { Volume }\end{array}$ \\
\hline Heavy metals & Heavy, Metals, Heavy metals \\
\hline Health Impact & Health, Impact, Health impact \\
\hline Inhalation exposure & Inhalation, Exposure, Inhalation exposure \\
\hline Metallurgy & Metallurgy \\
\hline Noise & Noise, Occupational, Adverse effects \\
\hline Occupational exposure & $\begin{array}{c}\text { Occupational, Exposure, Occupational expo- } \\
\text { sure, Adverse effects, Occupational diseases, } \\
\text { Mortality, Analysis }\end{array}$ \\
\hline Occupational health & Occupational, Health, Occupational health \\
\hline Risk assessment & Risk, Assessment, Risk assessment \\
\hline
\end{tabular}

\section{Selection criteria}

The next step was a detailed examination of papers, and at this point, studies were chosen based on relevant type of ores mined and refined. For instance, "kaolinite", "vermiculite mining", "asbestos" and "aluminium nanoparticles" were excluded from the list. Other than that, articles that were excluded include formal documentation such as proceedings of a meeting, report of policy strategies, new sites for mining, studies focusing mainly on the extraction process and neutralization of bauxite or social issues pertaining to the mining.

On the other hand, studies that were done in different areas such as Western Australia, India, Mozambique, Surinam and others, were included due to the lack of studies done in Malaysia. Also, articles were selected based on its context of bauxite mining impacting on the environment, which includes study of microbial life, plant growth and soil content after mining. 
An illustration for our selection criteria is as follows:

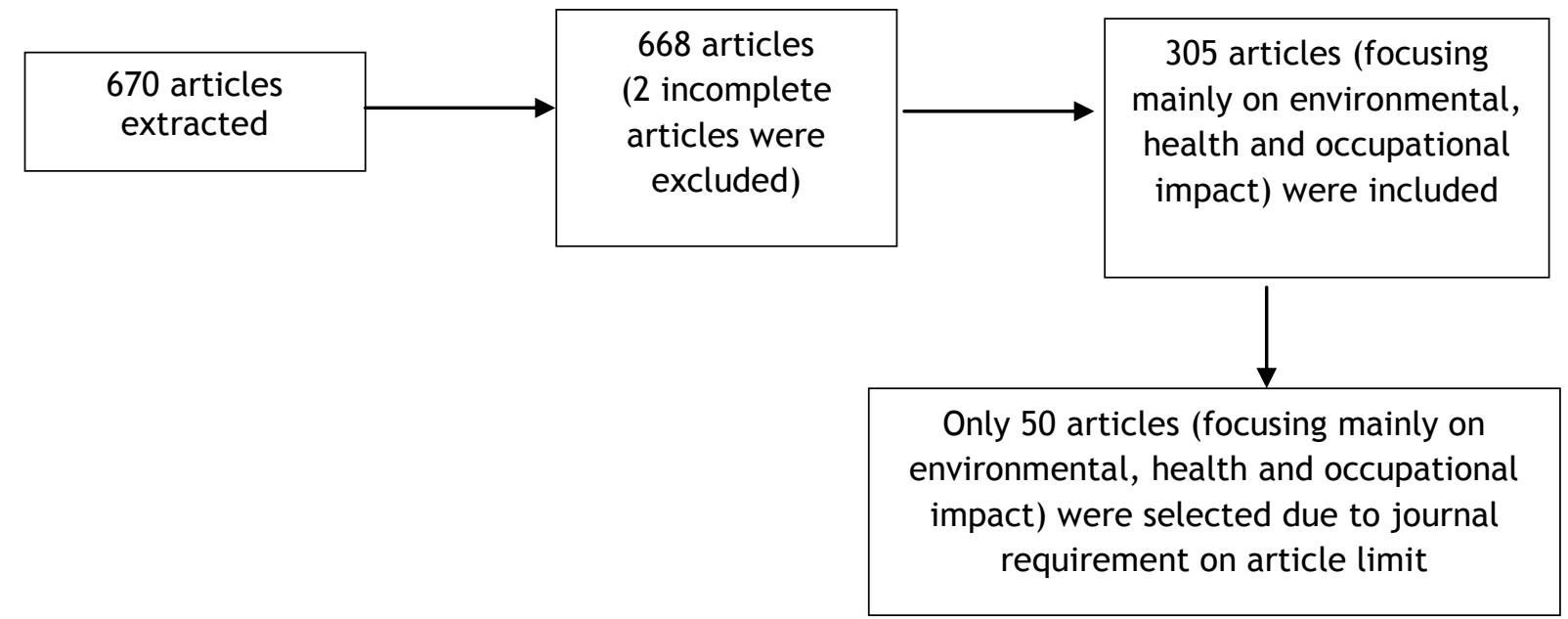

\section{RESULTS}

Based on our research, Australia is the world's largest producer of bauxite $(80,000$ tons), representing $29 \%$ of global production in $2015^{7}$. This is followed by China $(60,000$ tons, $22 \%)$ and Brazil (35,000 tons, $13 \%)$. These facts are reflected in Figure 1. It is pertinent to note that Malaysia's bauxite sector saw a dramatic increase in production from year 2014 to 2015, with 6.5 times increase, from 3,260 tons in 2014 to 21,200 tons in 2015. This was due to strong demand from China after Indonesia banned its exports to encourage domestic processing.

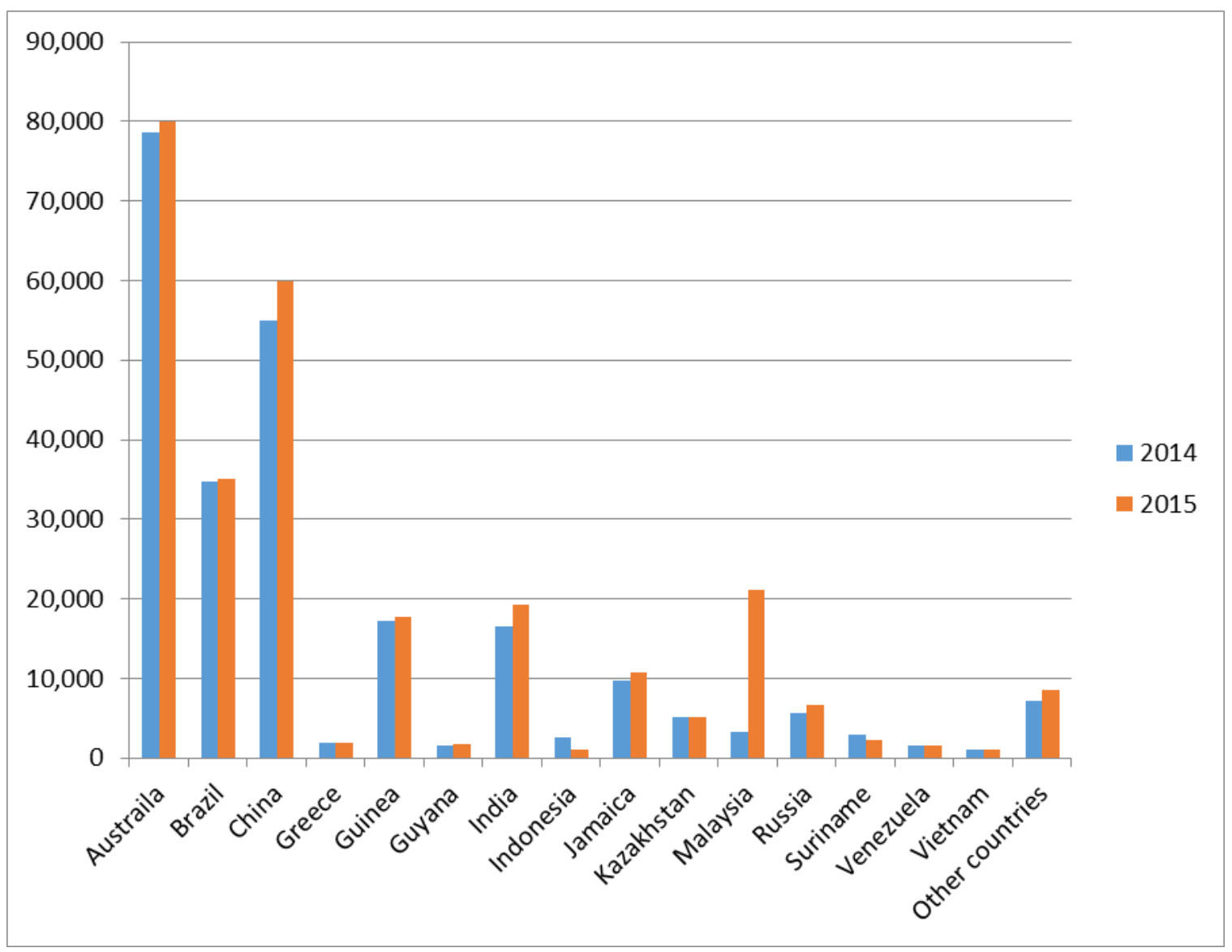

Figure 1: Amount of bauxite produced by country in 2014 and $2015^{7}$. 
In terms of bauxite reserves, the largest concentration of bauxite reserves is located in Guinea $(7,400,000$ tons), followed by Australia $(6,200,000$ tons), Brazil $(2,600,000$ tons), Vietnam $(2,100,000$ tons $)$, Jamaica $(2,000,000$ tons $)$ and
Indonesia $(1,000,000 \text { tons })^{7}$. As can be seen in Figure 2, compared to other bauxite-rich countries, Malaysia only has an estimated 40,000 tonnes of bauxite reserves.

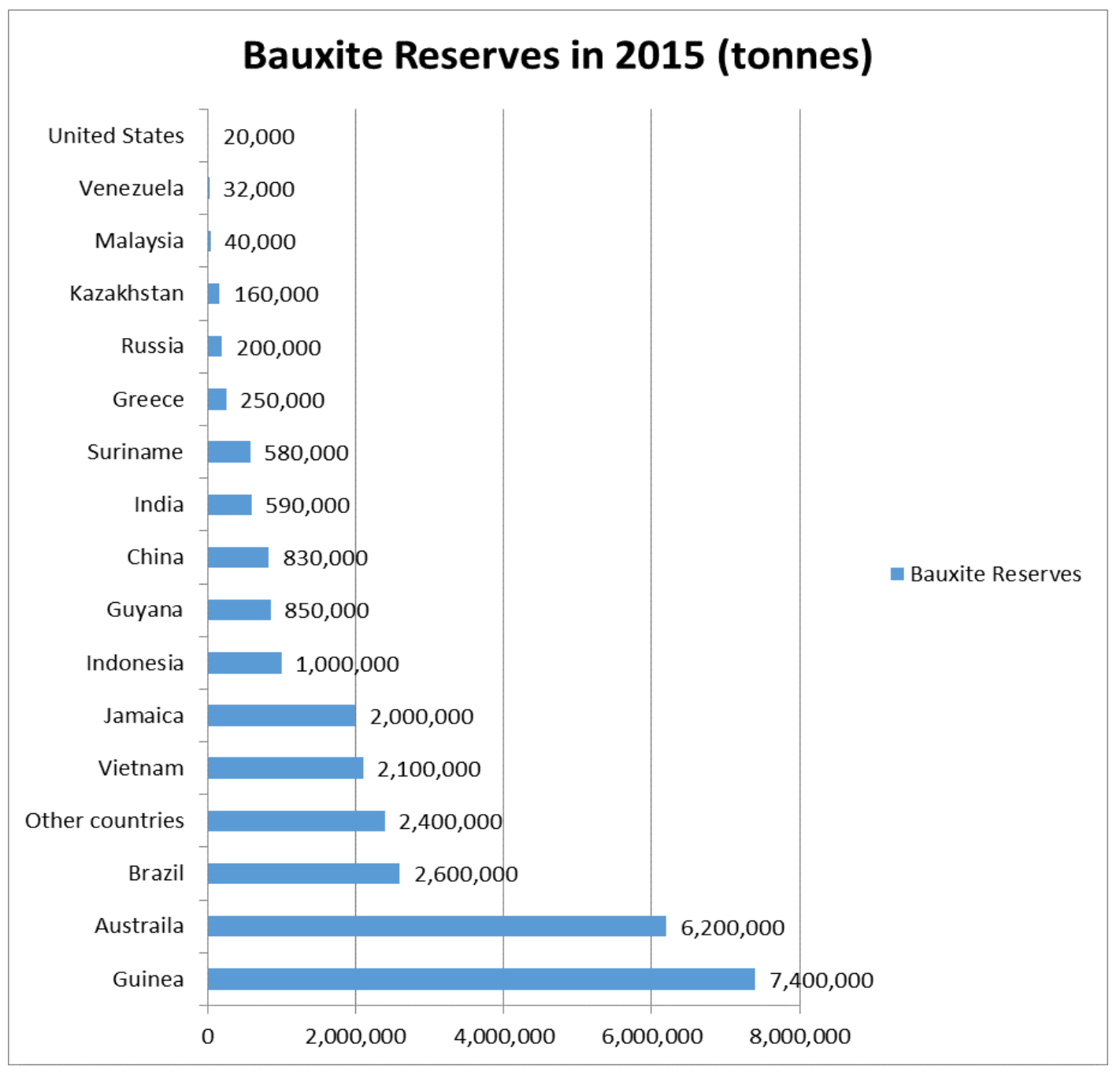

Figure 2: Bauxite reserves by country in $2015^{7}$.

\section{Impact Of Bauxite Contents And Bauxite Mining On The Environment}

Bauxite mining has a direct impact on the environment by polluting air, water sources and soil (Table 1). The environmental pollution exerts indirect effects on the health of miners and nearby communities.

\section{Air Pollution}

One of the primary concerns of bauxite is the release of airborne particulate matter due to mining activities. According to the International Standardization Organization (ISO) and British Standard Institute, dust is defined as 'small solid particles, usually below $75 \mu \mathrm{m}$ in diameter, that settles under their own weight but remain suspended for some time, ${ }^{8}$. In bauxite mining, activities such as site clearance and road building, open-pit drilling and blasting, loading and haulage, vehicular movement, ore and waste rock handling generate dust particles ${ }^{3}$.

In general, these particles can be classified into coarse and fine particles, where coarse particles have a 1-10 $\mu \mathrm{m}$ range while fine particles have a 0.1 $-1 \mu \mathrm{m}$ range . Coarse particles commonly originate from erosion, road and soil dust dispersion by wind, as well as anthropogenic activities such as vehicle emissions 9 . The coarse particles are of lesser concern as studies have shown that they tend to deposit in larger airways, hence can be coughed out. Fine particles, on the other hand, which are also produced during bauxite mining, can be lodged deep within alveoli, potentially leading to respiratory and cardiovascular problems ${ }^{8,10}$. 
Table 1: Types of environmental pollution in bauxite mining

\begin{tabular}{|c|c|c|}
\hline Air pollution & $\begin{array}{l}\text { Dust emissions (large particles ranging } 1-10 \mu \mathrm{m} \text {, fine } \\
\text { particles ranging } 0.1-1 \mu \mathrm{m}) \text { leading to cardiovascular and } \\
\text { respiratory problems } \\
\text { Reduced FEV1 after dust exposure }(\geq 100 \mathrm{mg} / \mathrm{m} 3) \text { of } 20 \text { years } \\
\text { among non-smokers }\end{array}$ & $\begin{array}{l}\text { Gelencser A KN } \\
\text { et.al } \\
\text { Donogue AM } \\
\text { et.al. }\end{array}$ \\
\hline Water pollution & $\begin{array}{l}\text { Leaching of iron, aluminium, arsenic, cadmium, lead, } \\
\text { nickel, manganese and mercury into drinking water sources } \\
\text { High concentration of heavy metals in sediments, which are } \\
\text { deposited in the water, further dissolves and deposits into } \\
\text { fish and benthic invertebrates, in which levels are 10-1000 } \\
\text { higher than in normal water. }\end{array}$ & $\begin{array}{l}\text { Petavratzi E KS } \\
\text { et.al } \\
\text { Yi YJ et.al. }\end{array}$ \\
\hline \multirow[t]{3}{*}{ Soil pollution } & $\begin{array}{l}\text { Soil contamination of heavy metals decrease microbial } \\
\text { activities which lowers its fertility } \\
\text { Low levels of carbon, nitrogen, phosphorus, potassium, } \\
\text { calcium and magnesium in post-mining soil in India }\end{array}$ & $\begin{array}{l}\text { Raymond AW } \\
\text { FE et.al. } \\
\text { Lad RJ et.al. }\end{array}$ \\
\hline & Insufficient soil depth for agriculture $(<15 \mathrm{~cm})$ & $\begin{array}{l}\text { Coke LB WC } \\
\text { et.al. }\end{array}$ \\
\hline & Habitat destruction and soil erosion & $\begin{array}{l}\text { Mertzanis A } \\
\text { et.al }\end{array}$ \\
\hline \multirow{2}{*}{$\begin{array}{l}\text { Food } \\
\text { contamination }\end{array}$} & Lead, cadmium, arsenic accumulation in vegetables & Zhou H et.al. \\
\hline & $\begin{array}{l}\text { High levels of lead found in sweet potato, exceeding CODEX } \\
\text { safety limit of } 0.1 \mathrm{mg} / \mathrm{kg}\end{array}$ & $\begin{array}{l}\text { Wright V JS } \\
\text { et.al. }\end{array}$ \\
\hline
\end{tabular}

Dust can react with the air in atmosphere, causing various chemical reactions, affecting soil, hence health of plants; meteorological and local climate, as well as penetrating into vegetation depending on particle size ${ }^{8}$. Dust can also dissolve in water, and flows down the food chain, where it is ingested by humans, or aquatic animals ${ }^{8}$.

Bauxite dust is visible due to high iron oxide content, having red colour which contaminates clothes, properties, vegetation, food and water sources $^{11}$. It is classified for occupational hygiene purposes as a 'nuisance dust' (coarse particles that decrease environmental amenity, damages machinery, decreases visibility, or acts as an irritant substance) or a "particle not otherwise specified"3, 8. Bauxite dust is detrimental because it can decrease visibility and result in visual changes to the environment $^{8}$. It can be deposited into machineries, reducing their life cycle and overall productivity ${ }^{8}$.

Bauxite dust is inhalable (respirable), and defined as dust particles less than $10 \mu \mathrm{m}$ in diameter or particulate matter of $\mathrm{PM}_{10}$ and $\mathrm{PM}_{2.5}{ }^{10}$. In Kuantan, 24-hour $\mathrm{PM}_{10}$ level ranged from 167-277 $\mu \mathrm{g} / \mathrm{m}^{3}$ during December 2015, which exceeds Malaysian National Ambient Air Quality Standard-2015 ${ }^{10}$. There is 'no safe level' for $\mathrm{PM}_{10}$ and $\mathrm{PM}_{2.5}$ as per the World Health Organization, because these particles can deposit in the alveoli during respiration and cause increased hospital admissions due to respiratory and cardiovascular problems ${ }^{8,10}$. Apart from damage to lungs, nose and throat, the eyes and exposed skin are at risk, as well as gastrointestinal tract $^{8}$. In some, it can also cause allergic reactions such as asthma or eczema ${ }^{8}$.

\section{Impact on Water Sources}

Most of the surface water in the world consists of streams, rivers, springs, ponds and lakes. These water sources closely interact with soil and rocks on the aforementioned surface, temperature and $\mathrm{pH}$ of environment, influencing adsorption and desorption of inorganic and organic matters ${ }^{12}$.

Water contamination by bauxite mining activities, especially drinking water sources, has the potential to cause harm due to components such as iron and aluminium as well as other toxic heavy metals found in trace amounts (arsenic, cadmium, lead, nickel, manganese and mercury $)^{8}$. This is especially true for heavy mining activities which have been aggressively carried out.

The most significant impact of heavy metals on the river is on sediments, aquatic organisms, and the water itself. Heavy metals do not degrade, depositing in sediments to be taken up by plants, animals or by feeding benthic animals ${ }^{13}$. According to a Chinese study conducted on a river exposed to mining, concentrations of heavy metals in sediments were 1000-100,000 times greater than water whereas concentration was 10-1000 times higher in fish and benthic invertebrates ${ }^{13}$. Fishes come into contact with heavy metals through water, via breathing and food chain ${ }^{13}$. Heavy metals are mobilized in water, are flushed downstream and deposited into clay minerals, or absorbed by algae at the lower trophic levels of food chain ${ }^{12}$. As heavy metals accumulate, this leads to critical levels, causing more problems by affecting organisms at higher food chains. 
Production of acidic water from mining activities can increase solubility of heavy metals and harm the aquatic ecosystems, especially at $\mathrm{pH} 5$ and below ${ }^{12}$. Heavy metals can be introduced to groundwater by agricultural and industrial activities, mining, and land filling, impacting drinking water and irrigation sources ${ }^{12}$. As heavy metals leach into soil and water, they can be released into air by surface erosion ${ }^{12}$.

In Kuantan, the river water near bauxite mining sites is the essential source for surrounding communities and there are several treatment plants located nearby ${ }^{10}$. Pollution of rivers by bauxite processing plants have resulted in closure of treatment plants ${ }^{11}$. Water samples taken from nearby residences have exceeded the Health Ministry's aluminium levels of $0.20 \mathrm{mg} / \mathrm{L}$ while mercury levels were $0.0093 \mathrm{mg} / \mathrm{L}$, nine times above the recommended level for raw water. However, continuous drinking water monitoring by Pahang State Health Department has reported that the concentration of aluminium and iron in drinking water has yet to exceed the National Drinking Water Quality Standard ${ }^{11}$.

\section{Impact on Soil}

Soil is one of the most important elements in the ecosystem as it provides nutrients for the plants and is also the major site of degradation and transference of biomass. Soil can form solid phase where it comprises mostly minerals and organic matters; or fluid phase when it interacts with water ${ }^{12}$. All of these phases involve ions interacting and entering the soil system. The excessive presence of heavy metals in soil is detrimental, as it inhibits such processes and biodegradation of organic contaminants ${ }^{14}$. In addition, higher soil contaminants lower its fertility. This can impact agricultural activity and decreases food quality and ultimately causing food shortages ${ }^{14}$.

The quality of soil is determined by the presence of organic carbon ${ }^{15}$. In a study conducted on Indian bauxite mines, mining soil showed low levels of carbon along with low nitrogen, phosphorus, potassium, calcium and magnesium, which are essential for healthy plant growth ${ }^{15}$. Moreover, soil in bauxite mines have high levels of $\mathrm{Al}$ (as bauxite ore is essentially $\mathrm{Al}_{2} \mathrm{O}_{3}, \mathrm{Fe}_{2} \mathrm{O}_{3}$ and $\mathrm{SiO}_{2}$ ), limiting the growth of microbes in soil ${ }^{15}$. Without microbiological activity, nutrients are not released into soil, restricting plant growth in acidic soil. This prevents post-mining biological land reclamation ${ }^{15}$. However, if there is contact of limestone and soil due to bauxite refining process, the reclaimed soil will be alkaline instead ${ }^{16}$.

Comparing reclaimed and un-mined bauxite lands, it is found that the major difference between the two is the depth of soil ${ }^{16}$. Un-mined lands have deeper soil, which supports deep-rooted trees and agricultural crops; while reclaimed soil has approximate depth of $15 \mathrm{~cm}$ or less and can only support a limited number of $\operatorname{crops}^{16}$. Studies have shown that vegetable crops, root crops and legumes require a minimum of $30 \mathrm{~cm}$, which is lacking in reclaimed land ${ }^{16}$.

In addition, open cast bauxite mining creates artificial pits with large volume of calcareous debris; this destabilizes the environmental balance by changing the geo-morphological processes ${ }^{17}$. Land clearing processes before mining, such as deforestation, forest fires, opening up new road networks for better access and waste disposal, lead to habitat destruction and soil erosion. This can further result in loss of bio-diversity, water pollution and increased turbidity ${ }^{17}$. These effects can be short-term, requiring a sizeable amount of time and resources to restore or can be severe to become irreversible ${ }^{17}$.

\section{Impact of Bauxite-contaminated Soil on Food Products}

Bauxite-contaminated soil can be detrimental to health, as its contents can contaminate soil and water sources used in agriculture. Food products has been identified as a major pathway for human exposure to heavy metals compared with inhalation of soil particles, skin contact and drinking water ${ }^{18}$. Heavy metals can easily be taken up by vegetable roots and get accumulated at high levels in edible parts, although vegetable species differ in their ability to take up and concentrate heavy metals ${ }^{18}$. Heavy metals that can accumulate in plant products include lead, cadmium and arsenic.

For instance, cadmium in soil can be mobilized and readily absorbed by plants and crops. This was seen in a Jamaican study, where crops from previous bauxite mining site contained high level of cadmium $^{19}$. Cadmium not only accumulates in plants, but also leaches into water supply and sources where it gets deposited in aquatic animals, which are later consumed by the community ${ }^{19}$. Chronic consumption of cadmium causes kidney and bone damage, cancer, low birth weight and spontaneous abortion ${ }^{19}$. Thus concerns should be raised regarding reclaimed bauxite mining sites for agricultural purposes.

Other issues include leaching of heavy metals into soil. Heavy metals can accumulate in crops. Among different crops planted in various locations, sweet potatoes showed the highest lead concentration, which is beyond the safety level of $0.1 \mathrm{mg} / \mathrm{kg}$ indicated by $\operatorname{CODEX}^{19}$. Lead poisoning is lethal, causes neurological disorders, as well as debilitating reproductive disorders and diminished intelligence after ingestion in children or newborns ${ }^{19}$. 


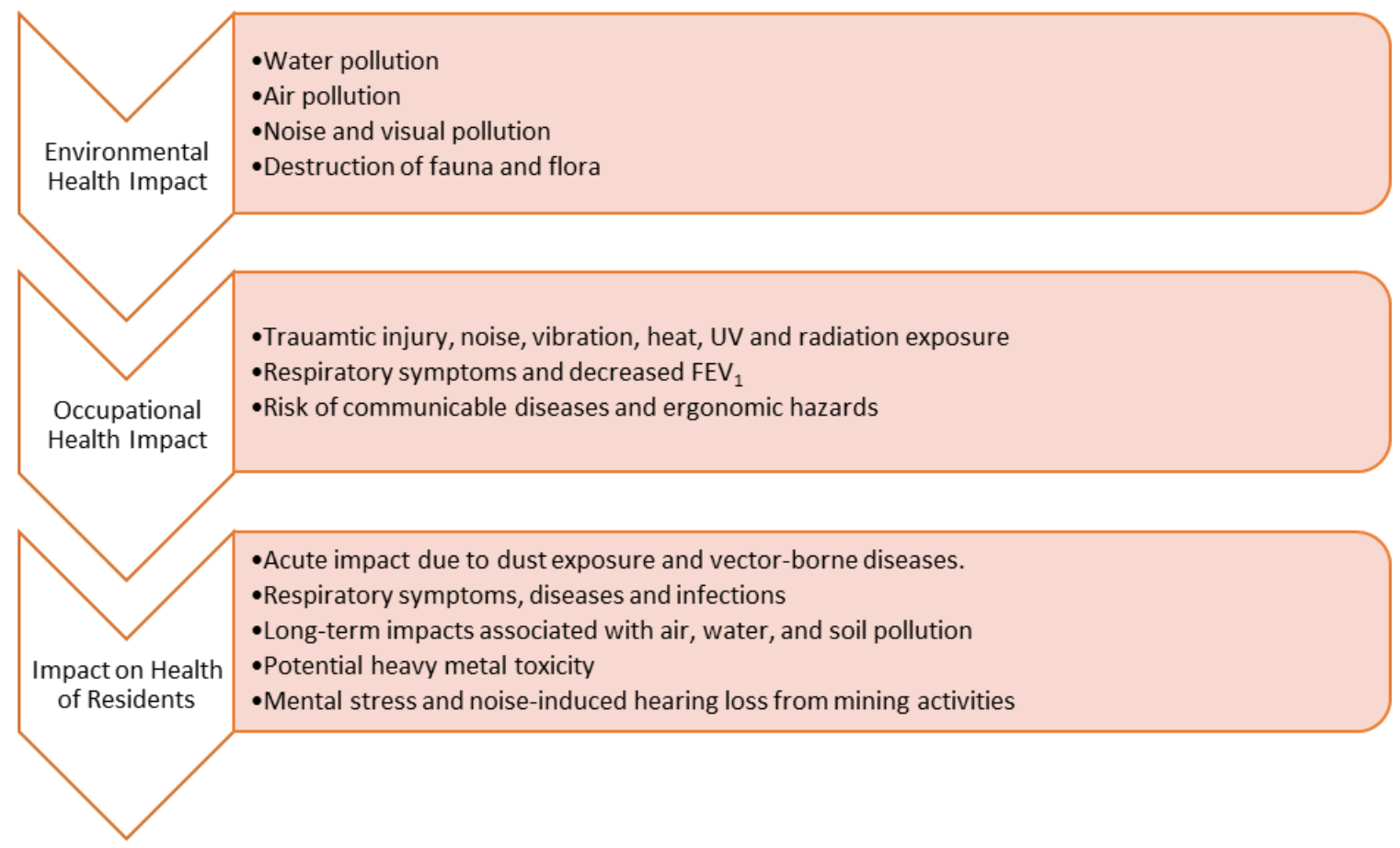

Figure 3: Various impacts of bauxite mining on the environment and on health ${ }^{3,11}$

\section{OCCUPATIONAL EXPOSURE TO BAUXITE MINING}

\section{Physical Hazards}

Physical hazards encountered in bauxite mining include noise, heat, humidity, and ergonomic problems such as vibration, ultraviolet radiation and radioactive materials $\mathrm{s}^{3,20}$. Both studies acknowledge the potential for traumatic injury and elaborate that injury in bauxite mining is uncommon compared to coal or metalliferous mining ${ }^{3}$.

Noise in bauxite mining originates from mining equipment and processes such as blasting, drilling, excavating and crushing ${ }^{3}$. Noise levels range from $85 \mathrm{~dB}$ to $106 \mathrm{~dB}$, and a study shows that this noisy environment within $10 \mathrm{~m}$ is potentially detrimental to health ${ }^{3,20,21}$. Furthermore, most miners have high exposure as mines are being operated round the clock $^{3,20,21}$. This exceeds the healthy noise levels range (less than $85 \mathrm{~dB}$ ) and acceptable duration of exposure (101-106 dB for 4-15 minutes) ${ }^{22}$. Hence, noise-induced hearing loss is an important occupational hazard due to bauxite mining ${ }^{3}$.

A study in India concluded that vibration dose to an individual depend on work circumstances and type of machineries used ${ }^{23}$. Whole-body vibration is a hazard in bauxite mining but not the hand-arm vibration due to machineries used such as excavators, drilling rigs, scrapers and haulage trucks ${ }^{3}$. The effects of whole-body vibration on miners can be reduced with proper maintenance of machineries.

As bauxite mining is concentrated in tropical climates, ultraviolet radiation exposures can contribute to skin cancers ${ }^{3,24}$. One study noted an increased incidence of melanoma among miners but it was not significant ${ }^{24}$. Another research noted that outdoor work does not increase the risk of melanoma ${ }^{3}$. However, heat and humidity result in heat-related illnesses, which include heat exhaustion and miliaria rubra ${ }^{3}$.

A few studies have noted radiation potential of bauxite, since it contains small amounts of radioactive materials such as uranium, thorium and potassium ${ }^{3}$. One study in Mozambique found very low radiation dose which was below the detection limits and radiation exposure risk ${ }^{25}$. Another study from Western Australia indicates that personal dose levels across a range of jobs were below the public exposure limits of $1.0 \mathrm{mSv}$ per year ${ }^{3}$. While continued monitoring is necessary, radioactivity does not significantly impact on the human health ${ }^{3}$.

\section{Chemical Hazards}

There are a few related chemical hazards because bauxite is biologically inert and is classified as a nuisance dust or 'particle not otherwise specified' in the context of occupational hygiene. However, increased respiratory symptoms, such as cough, wheeze and rhinitis, have been noted among bauxite miners, with self-reported symptoms ranging from $1.5 \%$ to $11.8 \% 3,26,27$. This is attributed to bauxite dust from breaking-blasting the crust and excavation, and loading of ore onto trucks. A study of bauxite miners (exposed to bauxite and silica) have shown non-specific airway responses, such as cough, mucous production and decreased forced expiratory volume in 1 second $\left(\mathrm{FEV}_{1}\right)^{26}$. Another study showed a significant decline in $\mathrm{FEV}_{1}$ of $7.3 \mathrm{~mL} /$ year which was associated with employment duration ${ }^{27}$. This association between employment 
duration and $\mathrm{FEV}_{1}$ was independent of bauxite exposure. Other studies have shown that cumulative exposure to bauxite was not linked to significant respiratory symptoms or lung function changes ${ }^{27,28}$.

A case of pulmonary fibrosis was reported after prolonged exposure to bauxite crushing and transport, and bauxite was found within fibrotic area during autopsy ${ }^{29}$. However, recent bauxite exposure studies in well-run facilities noted that bauxite is not associated with pneumoconiosis ${ }^{3,30}$.

\section{Cancer Incidence and Mortality}

A study among Australian bauxite and alumina workers in relation to mortality and cancer rates showed little evidence of increased all-cause cancers or combined cancer mortality ${ }^{24}$. Several studies support this, and noted that there is no increased risk of squamous and basal cell carcinoma despite ultraviolet exposure; an increased risk of melanoma and pleural mesothelioma reported in one Australian study was unrelated to environmental or occupational conditions of aluminium industries ${ }^{3,}$ 24. Instead, Friesen et al. observed that bauxite exposure may be associated with an increased risk of death due to non-malignant respiratory diseases $^{30}$.

\section{Biological Risks}

Important biological risks include communicable diseases such as dengue and malaria; hence, appropriate chemoprophylaxis and vector control is required $^{3}$. Other community-acquired infections such as human immunodeficiency virus (HIV) and tuberculosis may affect the employees ${ }^{3}$. Therefore, mining companies should invest in education, screening, early diagnosis and treatment as well as providing travel medicine consultation to their employees $^{3}$.

\section{Ergonomic Risks}

Bauxite mining has become highly mechanized, hardly requiring manual handling, hence ergonomic hazards are minimized ${ }^{3}$. Since mines operate nonstop, fatigue has become a concern due to long shifts and overtime. Measures that have been put into place include fatigue risk management and monitoring. Addressing staffing issues and ensuring appropriate rosters help in reducing fatigue.

\section{IMPACT ON THE HEALTH OF SURROUNDING COMMUNITIES}

There are not many papers that discuss the impact of bauxite mining on surrounding communities, because most mining sites are located in remote areas with well-defined boundaries. Only one paper by Abdullah et al. discusses this impact, by further dividing it into acute and chronic impacts ${ }^{11}$. Acute impact is associated with short-term dust exposure, road accidents and vector-borne diseases. Mental stress due to daily nuisance is also an acute impact which can progress to chronic effects after prolonged exposure ${ }^{11}$. Other long-term impacts are associated with air, water, and soil pollution due to mining activities ${ }^{11}$.

\section{Impact on Health due to Dust Particulate}

A study has described how large particles released into the environment from open mining processes contaminate property, water, food sources and clothes and affect personal comfort. These nuisance particles cause irritation of eyes, nose and throat ${ }^{31}$. These particles deposit on vegetation, making it unpalatable for human and livestock consumption ${ }^{11}$. Fine bauxite particles of $\mathrm{PM}_{10}$ and $\mathrm{PM}_{2.5}$ size penetrate deep into the respiratory system and have been associated with increased hospital admissions for cardiovascular and respiratory diseases as well as premature deaths ${ }^{31}$. This is of great concern in the paediatric groups because of relatively smaller lung size compared to adults, whilst receiving a higher dose of particles ${ }^{32}$. In Kuantan, there was an increasing trend of asthma and upper respiratory infections during 2015, compared to previous years. According to local health clinic data, this has been linked to the higher 24-hour $\mathrm{PM}_{10}$ levels ranging from 164 to $277 \mu \mathrm{g} / \mathrm{m}^{3}$ during the same time period, exceeding the Malaysian National Ambient Air Quality Standards $2015^{11}$.

\section{Impact on Health due to Contamination by Bauxite and Heavy Metals}

Water contamination by bauxite mining, especially drinking water, has potential for harm due to longterm ingestion of aluminium hydroxide, iron oxide and heavy metals ${ }^{11}$. Aluminium is a neuro-toxin and has been linked to Alzheimer disease, though there is insufficient evidence on causation; while in children, high levels of aluminium exposure has been associated with bone disease due to reduced phosphate absorption ${ }^{11,33}$. Meanwhile, iron oxide in bauxite can potentially cause iron overload upon chronic ingestion, leading to gastrointestinal symptoms, hepatic disease, cardio-myopathies, diabetes, joint and skin involvement in the form of hyper-pigmentation ${ }^{34}$.

Chronic exposure to toxic metals causes multiple organ toxicity and increases risk of malignancies ${ }^{11}$, 35-37. Heavy metals can accumulate in food sources and drinking water, eventually affecting the entire food chain. These show up in seafood and are ingested by humans in high concentrations. These heavy metals include lead, arsenic, mercury, cadmium, chromium, manganese and nickel, and can result in central and peripheral nervous system damage, impaired neuro-cognitive function, nephrotoxicity, hypertension, cardiovascular disease, dermatological manifestations and increased mortality ${ }^{35-44}$. In children, heavy metal toxicity is associated with increased risk of death from all causes, neuro-developmental delays, intellectual and behavioural issues, peripheral neuropathy and hearing loss ${ }^{38,40,43}$. 
Of special concern is mercury and cadmium toxicity. Chronic mercury toxicity leads to Minamata disease from ingestion of contaminated seafood containing methyl-mercury, or from occupational exposure which mainly targets the brain by crossing the blood-brain barrier, and resulting in neurological effects that include weakness, fatigue, mercurial tremor and widespread neuro-logical damage such as loss of motor control, ataxia, tremors, sensory loss affecting vision, hearing, and speech ${ }^{40,41}$. Chronic cadmium exposure results in nephro- and osteo-toxicity and manifests as 'Itai-Itai' ('OuchOuch') disease, characterised by multiple fractures, mixed pattern of osteoporosis, osteomalacia and renal tubular dysfunction ${ }^{42}$. This has been associated with lung malignancies and emphysema ${ }^{36}$.

\section{Impact on Health due to Noise}

Abdullah et al. reported that noise pollution affects bauxite miners and neighbouring communities, as mining is carried out around the clock ${ }^{11}$. Potential health effects include noise-induced hearing loss, loss of hearing sensitivity, and sleep disturbances. Noise has been associated with cardiovascular and physiological effects along with behavioural and cognitive impacts ${ }^{11}$. Residents living near mines are subjected to mental stress ${ }^{11}$. Due to high iron oxide content, nearby communities get tainted dark red and this visual disturbance can cause stress. The health impact of bauxite dust on individuals, water and food sources also exert its toll.

\section{DISCUSSION}

\section{Environmental Impact of Bauxite Mining}

The environmental impact of bauxite mining can be on air, water and soil. Under air pollution, the main hazard is nuisance dust which can obstruct vision ${ }^{3,8}$, deposits on vegetation, food, and airways, thus causing long term respiratory and cardiac diseases ${ }^{8}$, 11.

Details about water pollution are not known as no study was conducted to explore the effects of bauxite ingestion in humans. Moreover, drinking water pollution is not the only concern as bauxite and heavy metals in the sediments can be absorbed by aquatic animals, or plants, affecting various levels of food chain ${ }^{13}$.

Soil pollution impacts agricultural activities as the fertile topsoil is stripped bare and restoration efforts are not sufficient to return barren land to the former state ${ }^{16}$. Heavy metals in soil are absorbed, which raises issue of food safety among consumers $^{19}$. Moreover, habitat destruction reduces the diversity of flora and fauna, which is vital for identity of Malaysia as a tropical forest country.

\section{Occupational Health Hazards}

In terms of occupational health effects of bauxite mining, noise-induced hearing loss is a significant hazard, with poor hearing sensitivity and sleep disturbances, which can lead to cardiovascular, physiological, and mental health effects, impacting behavioural and cognitive performance ${ }^{11}$. Hearing conservation measures have been effective in reducing the rate of such decline ${ }^{3,45}$.

Another health hazard is vibration, especially wholebody vibration when compared to hand-arm vibration, due to machineries used. This vibration can cause or worsen spinal cord disorders ${ }^{3}$. Heat exhaustion and miliaria rubra has been reported due to heat and humidity but UV exposure and radiation at mining sites are not associated with increased risk of skin cancers or other health problems ${ }^{3,24,25}$.

Studies have linked respiratory symptoms such as cough, wheeze and rhinitis to bauxite mining ${ }^{3}$. In some earlier studies, bauxite exposure has been linked to small decrements in $\mathrm{FEV}_{1}$ but recent occupational health studies could not be linked to such reductions ${ }^{26-28}$. There has been a reported case of pulmonary fibrosis, but bauxite is not associated with pneumoconiosis.

In terms of cancer incidence, bauxite mining has not been associated with malignancies such as skin cancers or pleural mesothelioma, and not linked to increased or combined cancer mortality $3,24,30$.

\section{Impact on Surrounding Communities}

During our literature review, we found very few papers that discussed the impact of bauxite mining on surrounding communities because most mines are located in remote areas with well-defined boundaries. However, in Kuantan, mines are scattered, poorly defined and operate within or near communities; with bauxite potentially causing significant impacts on the health and lives of nearby populations ${ }^{11}$.

Acute impacts of mining activities include exposure to bauxite dust and vector-borne diseases ${ }^{11}$. Longterm effects of bauxite mining can be attributed to bauxite dust, comprising particles of varying size which can contaminate food sources and water supply, causing respiratory infections or diseases ${ }^{11}$. The potential of leaching of heavy metals and products of bauxite mining into nearby water sources is another concern as they have long-term effects on both adults and children such as neurotoxicity, nephrotoxicity, cardiovascular diseases, neuro-developmental delays as well as increased risk of malignancies and mortality ${ }^{11,35-37}$. The health of nearby residents is affected by noise pollution which may result in reduced hearing sensitivity and noise-induced hearing loss ${ }^{11}$. All these impacts will cause mental stress to nearby residents.

\section{PERMISSIBLE EXPOSURE LIMITS AND BIOLOGICAL EXPOSURE INDICES OF BAUXITE CONTENTS Permissible Exposure Limits (PELs) of Bauxite Contents}

Occupational Safety and Health Administration's (OSHA) permissible exposure limits (PELs) were set 
in 1970s and have not been updated since then ${ }^{46}$. Most of the PELs are outdated and scientific data indicates inadequacy of these limits to protect worker's health ${ }^{46}$. While OSHA's mandatory PELs in OSHA Z-1 Table remains in effect, it is recommended to utilize Occupational Exposure Limits (OELs) due to the belief that exposures above these OELs may be hazardous even though they comply with relevant PELs ${ }^{46}$.

Many countries have developed OELs for airborne vapours, particles and gases ${ }^{46}$. The American Conference of Governmental Industrial Hygienists (ACGIH) has issued the Threshold Limit Values (TLVs) for airborne concentrations of chemicals under conditions in which most workers are repeatedly exposed without any adverse events ${ }^{46}$. Malaysia utilizes the PELs issued under the Occupational Safety and Health Act 1994 (OSHA 1994), in Schedule 1 of the Occupational Safety and Health (Use and Standards of Exposure to Chemicals Hazardous to Health Regulations 2000) ${ }^{47,48}$. OELs for substances listed in OSHA Z-1 Table have been set and revised periodically ${ }^{46}$; these should be consulted for the latest values, and special notations, such as skin absorption.

\section{Biological Exposure Indices (BEls) of Bauxite Contents}

Biological exposure indices (BEls) are the levels that are observed in biological specimens such as exhaled air, blood and urine, of healthy workers who have chemical exposure similar to the workers with inhalation TLVs ${ }^{49}$. These provide guidance for biological monitoring and evaluating workers' exposure and health risk (dosage of exposure of a worker from a chemical is reflected by biological monitoring).

BEls are the concentrations below which most workers do not encounter detrimental health effects. The chemical, its metabolites, or a reversible biochemical change in chemical can be a BEls determinant. However, they are not a parameter of adverse effects to diagnose occupational illness. This does not demarcate between hazardous and non-hazardous exposures. It is plausible that increased health risk does not occur even when the individual's determinant concentration exceeds BEls. Investigations should be instigated BEls are the concentrations below which most workers do not encounter detrimental health effects. The chemical, its metabolites, or a reversible biochemical change in chemical can be a BEls determinant. However, they are not a parameter of adverse effects to diagnose occupational illness. This does not demarcate between hazardous and non-hazardous exposures. It is plausible that increased health risk does not occur even when the individual's determinant concentration exceeds BEls. Investigations should be instigated when worker's specimens persistently exceed BEls on various occasions, or majority of workers from the same workplace or shift have measurements exceeding BEls.

BEls are indices of 'uptake' of a chemical(s) while TLVs demonstrate potential inhalation 'exposure' of an individual or group via air monitoring. Discrepancies may be seen between biological monitoring and air monitoring data for a number of reasons:

- Physiological composition and health status of worker: body habitus, habits, diet, metabolic rate, age, gender, body fluid composition, medicine, pregnancy and disease state.

- Occupational exposures: work-rate, intensity and duration, temperature and humidity, coexposure to other irritants, skin exposure and other work habits.

- Non-occupational exposures: water and food, personal hygiene, residential air pollutants, alcohol and drug intake, cigarette smoking, or exposure to household products or chemicals from hobbies.

- Methodological causes: contamination of specimen and bias of selected analytical method.

- Positioning of air monitoring device in relation to worker's breathing zone.

- Size and bio-availability of particles.

- Varying effectiveness levels of personal protective devices.

\section{LEGAL REQUIREMENTS AND STANDARDS OF EXPOSURE TO BAUXITE IN MALAYSIA}

The Department of Environment (DOE), Ministry of Natural Resources and Environment of Malaysia have published guidelines for siting and zoning of industry and residential areas in 2012. This is intended as a guiding document to assist project owners and relevant Federal, State and Local authorities to decide on the suitability of a site for a particular industrial or non-industrial activity, with potentials to negatively impact the environment ${ }^{50}$.

The primary objective of guidelines is to ensure appropriate selection of a site to avoid or minimize environmental conflicts which could arise as a result of incompatibility between the proposed project or activity and its neighbors ${ }^{50}$. Avoiding conflicts through proper siting is an element of environmental planning to achieve long term project sustainability, which helps to reduce unnecessary cost of pollution control and improves public perception about the project. These guidelines are also applicable for extraction and production of natural resources such as minerals and rocks.

The Environmental Quality Act 1974 (EQA 1974) requires that any activity which is likely to release or discharge or emit any pollutant which may 
impact the environment, is required to obtain the relevant comment, consent or approval of the Director General of Environmental Quality, DOE ${ }^{50}$. These consents or approvals are regarding site's suitability assessment, Environmental Impact Assessment (EIA), written permission, approval, and license etc.

The EQA 1974 relates to the prevention, abatement, control of pollution and enhancement of environment from various industrial and nonindustrial activities and may give rise to waste or pollutants affecting the environmental quality ${ }^{50}$.

The term 'Mine' and 'Mining' is interpreted in the Mineral Development Act 1994 (Act 525) as:

- 'to mine' means 'intentionally to mine minerals and includes any operation directly or indirectly and necessary therefore or incidental thereto, and "mining" shall be construed accordingly'

- The term 'mineral' is 'a naturally occurring element or chemical compound that is formed as a result of geologic processes'

Mining is regulated as a 'prescribed activity' under the Environmental Quality Order 1987, and includes:

1. Mining of minerals in new areas where lease covers an area over 250 hectares.

2. Ore processing, including concentration of aluminium, copper, gold or tantalum.

3. Sand dredging involving an area of 50 hectares or more.

Mining is 'a process that begins with exploration and discovery of mineral deposits and continues through ore extraction and processing till the closure and remediation of work sites ${ }^{50}$. In the context of guidelines, buffer zone represents 'separation area' between two or more areas for mitigation of potential conflicts and protection of environment ${ }^{50}$. Buffer zones are intended to safeguard and protect human lives, property, comfort and well-being, and also sensitive ecological resources. The presence of adequate buffer zone represents primary means to determine whether the site is appropriate for particular industry or activity taking account of immediate and adjacent land use and characteristics of receptors around selected sites.

A buffer zone is the area within which sensitive or incompatible land uses are prohibited or special measures are necessary to ameliorate the impacts of an activity ${ }^{50}$. These areas are not alternative to prevention and control at source or to high standards of environmental management for the activities which have potential to impact environment. Buffer zone is an added measure to minimize off-site impacts of residues which persist despite preventive and mitigation measures.

Under the classification of industries and potentially polluting hazardous activities, bauxite mining is considered "high risk" due to its nature to discharge large quantities of wastewater containing high levels of residual contaminants, and generating large quantities of scheduled wastes, which are difficult to treat $^{50}$. A minimum distance of $1 \mathrm{~km}$ is indicated as a primary buffer.

\section{CONCLUSION}

This review has highlighted bauxite mining repercussions on the environment through destruction of ecosystem that include harming of the air, water, food, soil as well as flora and fauna of the mining areas. Bauxite mining affects the health of miners and surrounding communities, along with environmental pollution; this is particularly true in Kuantan due to the poor demarcation and proximity of mines to the neighbouring communities. There is still a knowledge gap regarding the long-term health impacts of bauxite mining because chronic illnesses take time to manifest later in life. Hence, a detailed research is required to identify the areas which require improvement to implement measures to control and manage impacts of bauxite mining on the environment and human health.

\section{CONFLICT OF INTEREST}

The authors reported no conflicts of interest.

\section{REFERENCES}

1. IAl. Fourth sustainable bauxite mining report. London, United Kingdom: International Aluminium Institute (IAI), 2008.

2. IAI. Bauxite residue management: best practice. UK: International Aluminium Institute (IAI), 2015.

3. Donoghue $A M$, Frisch N, Olney D. Bauxite mining and alumina refining: process description and occupational health risks. J Occup Environ Med. 2014;56(5 Suppl):S12-7.

4. Mitchell J, Manning GB, Molyneux M, Lane RE. Pulmonary fibrosis in workers exposed to finely powdered aluminium. Br J Ind Med. 1961;18:1023.

5. PK. T. The mineral industry of Malaysia. U.S. geological survey minerals year minerals yearbook. . 2004:15.1-.7.

6. Gardner JH, David TB. Bauxite mining restoration by Alcoa World Alumina Australia in Western Australia: Social, political, historical, and environmental contexts. Restoration Ecology. 2007;15(4):S3-S10.

7. Bray E. U.S. Geological Survey. Mineral Commodity Summaries: Bauxite and Alumina. . 2016:32-3.

8. Petavratzi E KS, Lowndes I. Particulates from mining operations: A review of sources, effects and regulations Minerals Engineering 2005 (18):1183-99.

9. Gelencser A KN, Turoczi B, Rostasi A, Hoffer Imre K et.al. The Red Mud Accident in Ajk (Hungary): Characterization and Potential 
Health Effects of Fugitive Dust. Environ Sci Technol 2011;45:1608-15.

10. Abdullah NH MN, Sulaiman LH, Zakaria TA, Rahim DA Potential Health Impacts of Bauxite Mining in Kuantan. Malays J Med Sci. 2016;23 (3):1-8.

11. Abdullah N, Mohamed N, Sulaiman L, Zakaria T, Rahim D. Potential Health Impacts of Bauxite Mining in Kuantan. Malays J Med Sci. 201623 (3):1-8.

12. HB B. Sources and Origins of Heavy Metals. Heavy Metals in the Environment. 2005:1-27.

13. Yi YJ YZ, Zhang SH. Ecological risk assessment of heavy metals in sediment and human health risk assessment of heavy metals in fishes in the middle and lower reaches of the Yangtze river basin. Environmental Pollution. 2011;159:257585.

14. Raymond AW FE. Heavy metals in contaminated soils: A review of sources, chemistry, risks, and best available strategies for remediation. ISRN Ecology. 2011(2011):1-50.

15. Lad RJ SJ. Impact of Bauxite Mining on Soil: A case study of Bauxite Mines at Udgiri, DistKolhapur, Maharashtra State, India. Internal Research Journal of Environmental Sciences. 2015;4 (2):77-83.

16. Coke LB WC, Hill VG. Environmental Impact of Bauxite Mining and Processing in Jamaica. Social and Economic Studies. 1987;36(1):289-333.

17. A M. The opencast bauxite mining in N.E. Ghiona: Ecoenvironmental impacts and geomorphological changes (Central Greece). Journal of Geography and Regional Planning. 2011;5(2):21-35.

18. Zhou H, Yang W, Zhou X, Liu L, Gu J, Wang W, et al. Accumulation of Heavy Metals in Vegetable Species Planted in Contaminated Soils and the Health Risk Assessment. Int J Environ Res Public Health. 2016;13(3).

19. Wright V JS, Omoruyi FO. Effect of Bauxite Mineralized Soil on Residual Metal Levels in Some Post Harvest Food Crops in Jamaica. Bull Environ Contam Toxicol 2012;89.

20. Wesdock JC, Arnold IM. Occupational and environmental health in the aluminum industry: key points for health practitioners. J Occup Environ Med. 2014;56(5 Suppl):S5-11.

21. SK N. Noise Impact Assessment and Prediction in Mines Using Soft Computing Techniques Rourkela, Odisha, India National Institute of Technology Rourkela; 2012.

22. Decibels D. Decibel Exposure Time Guidelines 2016 [23-05-16]. Available from: http:// dangerousdecibels.org/education/informationcenter/decibel-exposure-time-guidelines/.

23. Vanerkar AP, Kulkarni NP, Zade PD, Kamavisdar AS. Whole body vibration exposure in heavy earth moving machinery operators of metalliferrous mines. Environ Monit Assess. 2008;143(1-3):239-45.

24. Fritschi L, Hoving JL, Sim MR, Del Monaco A, MacFarlane E, McKenzie D, et al. All cause mortality and incidence of cancer in workers in bauxite mines and alumina refineries. Int $\mathrm{J}$ Cancer. 2008;123(4):882-7.

25. Carvalho FP, Matine OF, Taimo S, Oliveira JM, Silva L, Malta M. Radionuclides and radiation doses in heavy mineral sands and other mining operations in Mozambique. Radiation Protection Dosimetry. 2013;158(2):181-6.

26. Townsend MC, Enterline PE, Sussman NB, Bonney TB, Rippey LL. Pulmonary function in relation to total dust exposure at a bauxite refinery and alumina-based chemical products plant. Am Rev Respir Dis. 1985;132(6):1174-80.

27. Beach JR, de Klerk NH, Fritschi L, Sim MR, Musk AW, Benke G, et al. Respiratory symptoms and lung function in bauxite miners. Int Arch Occup Environ Health. 2001;74(7):489-94.

28. Dennekamp M, de Klerk NH, Reid A, Abramson MJ, Cui J, Del Monaco A, et al. Longitudinal analysis of respiratory outcomes among bauxite exposed workers in western Australia. Am J Ind Med. 2015;58(8):897-904.

29. Bellot SM, Schade van Westrum JA, Wagenvoort CA, Meijer AE. Deposition of bauxite dust and pulmonary fibrosis. Pathol Res Pract. 1984;179 (2):225-9.

30. Friesen MC, Fritschi L, Del Monaco A, Benke G, Dennekamp M, de Klerk N, et al. Relationships between alumina and bauxite dust exposure and cancer, respiratory and circulatory disease. Occup Environ Med. 2009;66(9):615-8.

31. Health aspects of air pollution: Results from the WHO project "systematic review of health aspects of air pollution in Europe". Copenhagen: World Health Organization (WHO), 2004.

32. Schuepp K, Sly P. The developing respiratory tract and its specific needs in regard to ultrafine particulate matter exposure. Pediatr Respir Rev. 2012;13:95-9.

33. Flaten TP. Aluminium as a risk factor in Alzheimer's disease, with emphasis on drinking water. Brain Res Bull. 2001;55(2):187-96.

34. Iron overload: Iron Disorders Institute; 2009 [cited 2016 June 10].

35. Ratnaike R. Acute and chronic arsenic toxicity. Postgrad Med J 2003;79(933):391-6.

36. Nawrot T, Plusquin M, Hogervorst J, Roels $H$, Celis $H$, Thijs $L$, et al. Environmental exposure to cadmium and risk of cancer: a prospective population-based study. Lancet Oncol. 2006;7 (2):119-26.

37. Barceloux D. Chromium. J Toxicol Clin Toxicol 1999;37(2):173-94.

38. Flora G, Gupta D, Tiwari A. Toxicity of lead: A review with recent updates. . Interdisciplinary Toxicology 2012;5(2):47-58.

39. Lustberg $M$, Silbergeld E. Blood lead levels and mortality. Arch Intern Med 2002;162(21):2443.

40. Satoh H. Occupational and environmental toxicology of mercury and its compounds. Ind Health. 2000;38(2):153-64.

41. Bernhoft R. Mercury Toxicity and Treatment: A Review of the Literature. J Environ Public Health 2012. 
42. Bernhoft R. Cadmium Toxicity and Treatment. ScientificWorldJournal 2013;2013(394652).

43. Crossgrove J, Zheng W. Manganese toxicity upon overexposure. NMR Biomed. 2004;17(8):544-53.

44. Das K, Das S, Dhundasi S. Nickel, its adverse health effects \& oxidative stress. Indian J Med Res 2008;128(4):412-25.

45. Donoghue AM, Frisch N, Dixon-Ernst C, Chesson BJ, Cullen MR. Hearing conservation in the primary aluminium industry. Occup Med (Lond). 2016;66(3):208-14.

46. OSHA. Permissible Exposure Limits - Annotated Tables Washington, US: Occupational Safety and Health Administration (OSHA); [cited 2016 April 15]. Available from: https: //www.osha.gov/ dsg/annotated-pels/.

47. ILO. Chemical Exposure Limits Geneva, Switzerland: International LAbour Organisation (ILO); 2016 [cited 2016 April 15]. Available from:

http://www.ilo.org/safework/info/publications /WCMS_151534/lang--en/index.htm.

48. Occupational Safety and Health (Use and Standards of Exposure of Chemicals Hazardous to Health) Regulations (2000).

49. ACGIH. Biological Exposure Indices (BEI) Introduction Ohio, US: American Conference of Governmental Industrial Hygienists (ACGIH); 2012 [cited 2016 April 15].

50. Department of Environment MoNRaEM. Guidelines for siting and zoning of industry and residential areas. 2012. 